\title{
Dampak Kualitas Sistem, Pengguna Sistem dan Organisasi dalam Pemanfaatan Kinerja Sistem Informasi Manajemen Rumah Sakit di RSU Dr. H. Koesnadi Bondowoso (Impact of System Quality, System Users and Organization in Utilization of Hospital Information Management System Performanced at General Hospital)
}

\author{
Demiawan Rachmatta Putro Mudiono, Sri Hernawati, Saiful Bukhori \\ Program Pasca Sarjana IImu Kesehatan Masyarakat Universitas Jember \\ Jalan Kalimantan No. 37, Kampus Tegalboto, Sumbersari, Jember Jawa Timur \\ E-mail: demiawanrpm@gmail.com
}

\begin{abstract}
Hospital Information Management System (HIMS) was part of a health information system that provided relevant information resources throughout the organization to supported effective decision made and hospital administration. This studied aims to analyzed the impact of system quality, system users, and organizations in the utilization of HIMS performanced. The type of researched used was the type of explanatory researched. The population in this studied amounted to 258 and 158 samples. Based on the tested results there was the influenced of system quality on system users with $t$ statistics 3,219 (t statistics $>t$ table 1.96). In addition there was no effected of system quality on the organization with $t$ statistics 0.483 and there was no organizational influenced on the user system with $t$ statistics 1.489. Furthermore there was the effected of system users on the utilization of SIMRS performanced with t statistics of 5.838 and there was an organizational influenced on the utilization of HIMS performanced with $t$ statistics 3.589. The results were interrelated between variables so that to realized the utilization of HIMS performanced.
\end{abstract}

Keywords: System quality, System Users, Organization, Utilization of

Abstrak

Sistem informasi Manajemen Rumah Sakit (SIMRS) adalah bagian dari sistem informasi kesehatan yang menyediakan sumber informasi secara relevan di seluruh rumah sakit untuk mendukung pengambilan keputusan yang efektif dan administrasi rumah sakit. Penelitian ini bertujuan untuk menganalisis dampak kualitas sistem, pengguna sistem, dan organisasi dalam pemanfaatan kinerja SIMRS. Jenis penelitian yang digunakan adalah jenis penelitian survey analitik. Populasi pada penelitian ini berjumlah 258 pekerja dan sampel berjumlah 158 pekerja. Berdasarkan hasil pengujian terdapat pengaruh kualitas sistem terhadap pengguna sistem dengan $t$ statistik 3,219 (t statistik $>t$ tabel 1,96) artinya semakin baik kualitas sistem yang diterapkan maka semakin besar pengguna sistem mengoperasikan aplikasi SIMRS. Selain itu tidak terdapat pengaruh kualitas sistem terhadap organisai dengan t statistik 0,483 (t statistik < t tabel 1,96) dan tidak terdapat pengaruh organisasi terhadap pengguna sistem dengan $t$ statistik 1,489 (t statistik $<t$ tabel 1,96). Selanjutnya terdapat pengaruh pengguna sistem terhadap pemanfaatan kinerja SIMRS dengan t statistik 5,838 (t statistik > $\mathrm{t}$ tabel 1,96) dan terdapat pengaruh organisasi terhadap pemanfaatan kinerja SIMRS dengan $t$ statistik 3,589 (t statistik > t tabel 1,96). Hasil tersebut saling berkaitan antar variabel sehingga untuk mewujudkan pemanfaatan kinerja SIMRS maka semua variabel harus saling mendukung guna memberikan peningkatan terhadap pemanfaatan kinerja SIMRS.

Kata kunci : Kualitas sistem, Pengguna Sistem, Organisasi, Pemanfaatan kinerja SIMRS 


\section{Pendahuluan}

Sistem informasi Manajemen Rumah Sakit (SIMRS) adalah bagian dari sistem informasi kesehatan yang menyediakan sumber informasi secara relevan di seluruh rumah sakit untuk mendukung pengambilan keputusan yang efektif dan administrasi rumah sakit (Balaraman \& Kosalram, 2013). MEASURE Evaluation's menyebutkan bahwa tujuan SIMRS adalah untuk menghasilkan informasi berkualitas tinggi yang dapat digunakan di semua unit untuk pengambilan keputusan.

Peraturan Menteri Kesehatan Republik Indonesia Nomor 82 Tahun 2013 Tentang Sistem Informasi Manajemen Rumah Sakit (SIMRS) pada pasal 3 menyebutkan bahwa setiap rumah sakit wajib menyelenggarakan SIMRS (Menteri Kesehatan Republik Indonesia, 2013). Peraturan tersebut menjadi acuan bagi seluruh rumah sakit untuk menerapkan sebuah aplikasi SIMRS.

RSU Dr. H. Koesnadi Bondowoso merupakan rumah sakit pemerintah tipe $B$ dan telah menerapkan SIMRS sejak tanggal 14 februari 2015. Akan tetapi penerapan SIMRS tersebut masih kurang optimal dimana masih mengalami permasalahan-permasalahan sehingga mengakibatkan pemanfaatan yang diterima pengguna sistem dan organisasi tidak sesuai dengan harapan.

Kesuskesan penerapan SIMRS dapat dilihat dari beberapa faktor yaitu faktor manusia, lingkungan, dan teknologi. Faktor manusia merupakan hal yang perlu diperhatikan dalam kesuksesan penerapan SIMRS karena manusia termasuk bagian dari pengguna data yang terlibat dengan SIMRS. Faktor lingkungan dibagi menjadi 2 yaitu peraturan dan manajemen. Peraturan terdiri dari undang-undang/ kebijakan mengenai keamanan, kerahasiaan dan hak akses data. Sedangkan manajemen SIMRS mencakup kegiatan seperti pembiayaan, sumber daya manusia, pelatihan dan pendidikan berkelanjutan, manajemen informasi, dan pembangunan infrastruktur. Faktor teknologi mencakup keseluruhan proses pengumpulan, pembersihan, dan pengelolaan data dari berbagai sumber, serta pembuatan dan pendistribusian informasi kesehatan yang ada pada SIMRS (MEASURE Evaluation, 2017)

\section{Metode Penelitian}

Jenis penelitian yang digunakan adalah jenis penelitian survey analitik atau explanatory Multidisciplinary Journal, 1(1), Agustus 2018 research dengan rancangan yang digunakan adalah rancangan cross sectional. Populasi pada penelitian ini berjumlah 258 dan Sampel berjumlah 158 yang dibagi menjadi 3 hak akses yaitu top manajemen, middle manajemen dan lower manajemen dengan menggunakan teknik disproportionate stratified random sampling.

Teknik perolehan data dengan pengukuran menggunakan lembar kuesioner.

Pengumpulan data dilakukan dengan membagikan kuesioner kepada pengguna sistem secara langsung dan dengan wawancara terstruktur kepada pegawai. Teknik analisis data dilakukan dengan metode Partial Least Square (PLS).

\section{Hasil Penelitian}

\section{Evaluasi Outer Model}

Analisis outer model dilakukan untuk memastikan bahwa measurement yang digunakan layak untuk dijadikan pengukuran. Analisis outer model dapat dilihat dari beberapa indikator sebagai berikut :

a. Convergen validity

Uji validitas konvergen dalam SEM PLS dengan indikator reflektif dinilai berdasarkan loading factor (korelasi antara skor komponen dengan skor konstruk) indikator-indikator yang mengukur konstruk tersebut. Pada tahap penelitian pengembangan skala, jika nilai loading factor berkisar lebih dari 0,50 maka dianggap signifikan (Hair et all, 2006 dalam Jogiyanto 2011).

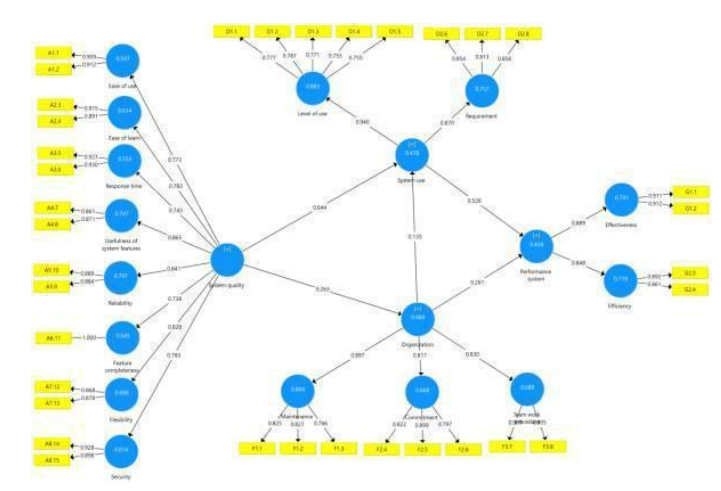

Figure 1. Measure Model Results

Pada gambar 1 diatas dapat dilihat bahwa 
hasil uji validitas konvergen memberikan nilai loading factor diatas atau lebih dari 0,50 artinya telah memenuhi uji validitas konvergen.

b. Uji Construct Reliability dan Validity Hasil uji validitas juga dapat dilihat dari nilai Average Variance Extracted (AVE), yaitu nilai dikatakan valid jika lebih dari 0,5 . Sedangkan hasil uji reliabilitas dapat dilihat dari dapat dilihat pada nilai composite reliability dan cronbachs alpha, nilai dari kedua uji tersebut harus >0,6. Tabel 1. Hasil Uji Construct Reliability dan Validity

\begin{tabular}{|c|c|c|c|}
\hline & $\begin{array}{l}\text { Composite } \\
\text { Reliability }\end{array}$ & AVE & Keterangan \\
\hline \multicolumn{4}{|l|}{ System } \\
\hline quality & 0.942 & 0.519 & Reliabel \\
\hline System use & 0.899 & 0.527 & Reliabel \\
\hline $\begin{array}{l}\text { Organization } \\
\text { Performance }\end{array}$ & 0.894 & 0.515 & Reliabel \\
\hline system & 0.859 & 0.605 & Reliabel \\
\hline \multicolumn{4}{|c|}{$\begin{array}{l}\text { Berdasarkan tabel } 1 \text { dapat dilihat bahwa semua } \\
\text { nilai Average Variance Extracted (AVE) berada } \\
\text { diatas nilai } 0,5 \text { yang berarti model tetsebut } \\
\text { dikatan bagus dan valid dalam mengukur } \\
\text { variabel latennya. Sedangkan nilai composite } \\
\text { reliability dan cronbachs alpha berada diatas } 0,6 \\
\text { yang berarti semua variabel dianggap reliabel } \\
\text { sebagai instrumen penelitian. }\end{array}$} \\
\hline
\end{tabular}

\section{Hasil II}

\section{Evaluasi Inner Model}

Analisa inner model dapat dilihat dari nilai RSquare. Nilai $R$-Square merupakan uji Godness of Fit (GoF) dengan melihat $R$-Square $\left(R^{2}\right)$ pada setiap variabel laten endogen. Apabila nilai mendekati angka 1 maka variabel eksogen memberikan semua informasi yang dapat memprediksi variabel endogen, akan tetapi jika nilai semakin kecil maka kemampuan varibel endogen dalam menjelaskan variabel eksogen semakin terbatas.

Tabel 2. Hasil uji nilai $R$-Square

\begin{tabular}{ll}
\hline Variabel & $R$-Square \\
\hline Performance system & 0.453 \\
Organization & 0.130 \\
System use & 0.586 \\
\hline ari tabel 2 dapat dilihat & bahwa variabel \\
2
\end{tabular}

Multidisciplinary Journal, 1(1), Agustus 2018 berarti $45 \%$ variabel performance system dipengaruhi oleh variabel organization dan system use. Sedangkan variabel organization memiliki $R^{2}$ 0,130 dan variabel system use memiliki nilai $R^{2} 0,586$, hal ini berarti $13 \%$ variabel organization dipengaruhi oleh system quality dan $58 \%$ variabel system use dipengaruhi oleh organization dan system quality.

\section{Hasil III}

\section{Evaluasi Pengujian Hipotesis}

Tabel 3. Hasil uji hipotesis

$\begin{array}{lcc}\text { Original } & \mathbf{T} & \mathbf{P} \\ \text { Sample } & \text { Statistics } & \text { Values }\end{array}$

\begin{tabular}{|c|c|c|c|}
\hline $\begin{array}{l}\text { System } \\
\text { quality -> } \\
\text { Organization }\end{array}$ & 0.059 & 0.483 & 0.630 \\
\hline $\begin{array}{l}\text { System } \\
\text { quality -> } \\
\text { System use }\end{array}$ & 0.318 & 3.219 & 0.001 \\
\hline $\begin{array}{l}\text { Organization } \\
\text {-> System } \\
\text { use }\end{array}$ & 0.083 & 1.489 & 0.137 \\
\hline $\begin{array}{l}\text { System use } \\
-> \\
\text { performance } \\
\text { system }\end{array}$ & 0.406 & 5.838 & 0.000 \\
\hline $\begin{array}{l}\text { Organization } \\
-> \\
\text { performance } \\
\text { system }\end{array}$ & 0.233 & 3.589 & 0.000 \\
\hline
\end{tabular}

Dari tabel 3 dapat dilihat bahwa terdapat 3 pengaruh positif yaitu System quality $->$ System use dengan t statistik 3,219, System use -> performance system dengan $t$ statistik 5,838 dan Organization $->$ performance system dengan $t$ statistik 3,589, nilai tersebut yaitu lebih besar dari $t$ tabel (t statistik $>t$ tabel 1,96). Selain itu juga tidak terdapat pengaruh positif yaitu System quality $->$ Organization dengan $t$ statistik 0,483 dan Organization -> System use dengan $t$ statistik 1,489 , nilai tersebut yaitu lebih kecil dari $\mathrm{t}$ tabel (t statistik < t tabel 1,96).

\section{Pembahasan}

Hasil dari pengujian hipotesis 1 menyatakan bahwa tidak terdapat pengaruh antara variabel system quality terhadap organization. Hasil pengujian menunjukan 
bahwa nilai t statistik $<\mathrm{t}$ tabel yaitu $0,483<1,96$ dan $p$ value $>a$ yaitu $0,630>0,05$. Hasil ini menunjukkan bahwa teori Riganta (2008)

menyatakan bahwa kualitas sistem mempengaruhi organisasi tidak berlaku dalam penerapan sistem. Dari pengamatan yang dilakukan peneliti, hal ini disebabkan karena sering menganti-ganti penyedia sistem. Sehingga banyak perubahan terhadap fitur yang ada pada aplikasi dan dampak yang terjadi yaitu kualitas sistem yang tidak baik. Temuan tersebut berbeda dengan penelitian ini bahwasannya RSU Dr. H. Koesnadi Bondowoso telah melakukan pergantian vendor berkali-kali, akan tetapi kualitas yang ada pada aplikasi SIMRS hingga saat ini sudah baik. Selain itu teori Dewi et all (2014) juga menyebutkan bahwa kualitas sistem tidak mempengaruhi organisasi. Dari pengamatan yang dilakukan peneliti, hal ini disebabkan oleh belum adanya pemeliharaan (maintenance) secara berkala yang dilakukan oleh teknisi terhadap sistem. Hal ini sesuai dengan temuan lapang bahwa RSU Dr. H. Koesnadi Bondowoso masih belum melakukan pemeliharaan (maintenance) pada jaringan, perangkat keras maupun perangkat lunak secara berkala.

Hasil dari pengujian hipotesis 2 menyatakan bahwa terdapat pengaruh antara variabel system quality terhadap system use. . Hasil pengujian menunjukan bahwa nilai $t$ statistik $>t$ tabel yaitu $3,219>1,96$ dan $p$ value $<$ a yaitu 0,001 < 0,05. Penelitian ini menunjukkan bahwa semakin baik kualitas sistem yang diberikan oleh aplikasi SIMRS maka semakin besar pula pengguna sistem mengoperasikan aplikasi SIMRS. Hasil penelitian ini didukung oleh pendapat Erimalata (2016) yang mengemukakan jika kualitas sistem mendorong kearah peningkatan penggunaan sistem informasi dan jika kualitas sistem memiliki pengaruh terhadap pengguna sistem, maka akan menghasilkan minat pengguna sistem untuk sering melakukan proses pengoperasian sistem.

Hasil dari pengujian hipotesis 3 menyatakan bahwa tidak terdapat pengaruh antara variabel organization terhadap system use. Hasil pengujian menunjukan bahwa nilai $t$ statistik $<\mathrm{t}$ tabel yaitu $1,489<1,96$ dan $\mathrm{p}$ value $>$ a yaitu 0,137 >0,05. Hasil ini didukung oleh penelitian Dewi et all (2014) menyatakan bahwa organisasi mempengaruhi pengguna sistem tidak berlaku dalam penerapan sistem. menyebutkan bahwa meskipun atasan telah memberikan arahan dalam menajalankan tugasnya namun petugas operator sistem informasi rekam medis belum pernah mengikuti pelatihan sehingga belum bisa mengoptimalkan kinerja sistem informasi rekam medis sebab petugas kesulitan dalam menyelesaikan laporan-laporan dengan sistem informasi serta petugas juga belum bisa mengatasi jika terjadi error. Berdasarkan teori tersebut, sesuai dengan temuan lapang bahwa pimpinan telah

memberikan komitmen mengenai pengoperasian SIMRS. Komitmen tersebut adalah setiap unit wajib melakukan penginputan data ke dalam aplikasi SIMRS. Pimpinan juga melakukan pelatihan terhadap pengguna sistem akan tetapi pelatihan tersebut hanya dilakukan oleh kepala unit atau perwakilan dari unit dan pelatihan tersebut hanya dilakukan jika ada kebutuhan fungsional yang berubah. Pelatihan tersebut dirasa kurang karena pelatihan hanya diberikan ke perwakilan unit dan untuk jadwal pelatihan tidak berkala.

Hasil dari pengujian hipotesis 4 menyatakan bahwa terdapat pengaruh antara variabel system use terhadap performance system. Hasil pengujian menunjukan bahwa nilai $t$ statistik $>t$ tabel yaitu 5,838 $>1,96$ dan $p$ value $<\alpha$ yaitu $0,000<0,05$. Hasil penelitian ini menunjukkan bahwa keberhasilan kinerja aplikasi SIMRS dapat memberikan manfaat terhadap kinerja pengguna sistem. Hal ini sesuai dengan penelitian Radityo \& Zulaikha (2007) yang menyatakan bahwa pengguna sistem memiliki pengaruh kuat terhadap manfaat yang diberikan oleh SIMAWEB. Apabila penggunaan SIMAWEB secara intens atau tinggi maka manfaat yang diberikan oleh SIMAWEB mengalami peningkatan.

Hasil dari pengujian hipotesis 5 menyatakan bahwa terdapat pengaruh antara variabel organization terhadap performance system. Hasil pengujian menunjukan bahwa nilai $t$ statistik $>t$ tabel yaitu 3,589>1,96 dan $p$ value $<\alpha$ yaitu $0,000<0,05$. Berdasarkan hasil analisis data diatas, penelitian menyatakan bahwa organisasi memiliki pengaruh positif terhadap terhadap manfaat yang dirasakan dalam keberhasilan kinerja SIMRS. Hal ini sesuai dengan temuan dari Sari (2016) yang menyebutkan bahwa organisasi memiliki efek signifikan dalam mempengaruhi manfaat sistem.

Menurut hasil penelitian, organisasi menunjukkan pengaruh signifikan terhadap manfaat keberhasilan sistem. Dorongan dari organisasi secara signifikan dapat memberikan motivasi untuk meningkatkan persepsi kebermanfaatan dibandingkan dengan faktor 
teknologi. Berdasarkan temuan dilapang bahwa kondisi saat ini organisasi telah menerapkan komitmen yang baik. Komitmen tersebut yaitu setiap pengguna sistem wajib menginputkan data kedalam aplikasi SIMRS. Selain itu pimpinan juga bertanggung jawab atas pengoperasian aplikasi SIMRS sehingga pengguna sistem tidak perlu khawatir dalam menginputkan data kedalam aplikasi SIMRS. Manajemen juga selalu melengkapi kebutuhan yang berkaitan dengan penerapan aplikasi SIMRS mulai dari perangkat keras (jaringan, server, PC maupun printer) dan perangkat lunak yang dibangun secara terintegrasi.

\section{Simpulan dan Saran}

Berdasarkan pengujian dapat disimpulkan bahwa quality system memiliki pengaruh terhadap system use, organization memiliki pengaruh terhadap performance system dan system use memiliki pengaruh terhadap performance system. Selanjutnya quality system tidak memiliki pengaruh terhadap organization dan organization juga tidak memiliki pengaruh terhadap system use.

\section{Ucapan Terima Kasih}

Terima kasih kepada Direktur RSU. H. Koesnadi Bondowoso yang telah berkenan memberikan ijin atas pelaksanaan penelitian ini.

\section{Daftar Pustaka}

Balaraman, P., \& Kosalram, K. (2013). E Hospital Management \& Hospital Information Systems - Changing Trends. International Journal of Information Engineering and Electronic Business, 5(1),
50-58.

Dewi, F. T. L., Farlinda, S., \& Hikmah, F. (2014). Evaluasi Sistem Informasi Rekam Medis

(SIMRM) dengan Metode Human Organization Technology (HOT)-Fit Model Di Instalasi Rekam Medik Rumah Sakit Kalisat Tahun 2014.

Erimalata, S. (2016). Pendekatan Hot-Fit Framework dalam Generalized Structural Component Analysis pada Sistem Informasi Manajemen Barang Milik

Daerah: Sebuah Pengujian Efek Resiprokal. Jurnal Akuntansi Dan Investasi, 17(2), 141-157.

Jogiyanto. (2011). Konsep dan Aplikasi Struktural Equation Modeling Berbasis

Varian dalam Penelitian Bisnis.

Yogyakarta: Unit Penerbit dan Percetakan

STIM YKPN.

MEASURE Evaluation. (2017). Health Information System Strengthening Model

Peraturan Menteri Kesehatan Republik Indonesia Nomor 82 Tahun 2013 tentang Sistem Informasi Manajemen Rumah Sakit.

Radityo, D., \& Zulaikha. (2007). Pengujian Model DeLone and McLean Dalam

Pengembangan Sistem Informasi Manajemen ( Kajian Sebuah Kasus ). Simposium Nasional Akuntansi X, 1-25.

Riganta. (2008). Penyebab Kegagalan Dan Keberhasilan Penerapan Sub Sistem Informasi di RSUD Dr. Achmad Mochtar Bukit Tinggi.

Sari, M. M., Sanjaya, G. Y., \& Meliala, A. (2016). Evaluasi Sistem Informasi Manajemen Rumah Sakit ( SIMRS ) Dengan Kerangka HOT - FIT. Seminar Nasional Teknologi Informasi Indonesia, 203-208. 